\title{
Ability Grouping as a Way towards More Academic Success in Teaching EFL - A Case of Iranian Undergraduates
}

\author{
Bahareh Khazaeenezhad ${ }^{1}$, Hossein Barati ${ }^{1} \&$ Mehdi Jafarzade ${ }^{1}$ \\ ${ }^{1}$ University of Isfahan, Isfahan, Iran \\ Correspondence: Bahareh Khazaeenezhad, University of Isfahan, Iran. E-mail: b.khazaeenezhad@gmail.com
}

Received: March 24, 2012 Accepted: April 27, 2012 Online Published: July 1, 2012

doi:10.5539/elt.v5n7p81 URL: http://dx.doi.org/10.5539/elt.v5n7p81

\begin{abstract}
This research is an attempt to find out if grouping learners, through using a placement test will significantly help students become more successful in learning English. 320 non-English major undergraduates studying at the University of Isfahan participated in this research. The final scores of 121 freshmen who attended their general English courses in homogenised classes were compared with those of 199 freshmen who did not undergo any placement procedure. The analysis of data suggested that grouping the learners and dividing them into different ability groups had a significant impact on the participants' academic success, in their course of general English. In addition, the results suggested that ability grouping provides sufficient ground for methodological decisions and hence sequencing of teaching materials and procedures
\end{abstract}

Keywords: ability grouping, exposure to English, academic success, general English course

\section{Introduction}

It has been commonplace in studies on language learning to see Learning English as a Foreign Llanguage (EFL) has not been an exception. A survey on the literature of research in the field would reveal the amount of time and efforts which have been put into innovative ways of teaching English to non-natives (e.g. Bednarek, 2008; Seidlhofer, 2004) to help them learn more effectively. One such group of efforts can be summarized in the changes in students' grouping based on their ability level (i.e. homogenisation).

Since the introduction of formal education, the differences in the level of academic achievement and abilities among students have posed many challenges to teachers. Teachers are expected to cater for these differences within the short class time. What happens in the class is that the average student may find the lesson of the right level of difficulty whereas the slow learner tends to require more time. At the same time, the fast learner may be bored by the lengthy and simple explanations appropriate to average learners. When the needs of the weak and advanced learners are not met and the class process is not geared to the appropriate ability level of the students, problems will occur. Ability grouping therefore has been referred to as a panacea for most of such problems (et al. Ireson, Hallam, Hack, Clark, \& Plewis, 2002).

Students' varying abilities and academic achievement have been well researched during the last couple of decades. Yet the findings reported so far are inconclusive: some recommend individualized teaching whereas some others suggest ability grouping as successful methods within the classroom (e.g., Argy, Brewer, \&, Rees, 1996). In Iran, however, few studies have addressed the problem and hence there is little evidence whether homoginising students would help promoting Iranians' EFL achievement. The present study therefore aims to investigate if ability grouping may function as a successful way of meeting students' differences. In other words, we intend to find out if homoginising learners, through using a placement test, will significantly help them become more successful in their learning of English.

\section{Literature Review}

There have been numerous studies in the literature on placing language learners in various groups according to their proficiency or level of English. One such study (Slavin, 1987) defined ability grouping as "some means of grouping students for instruction by ability or achievement so as to reduce their heterogeneity" (p. 79). It is believed that in this way students are easier to manage and keep attentive (Hallinan \& Sorensen, 1983). Further, Kerckhoff (1986) pointed out that high ability students can move faster without having to slow down for their less competent friends. In contrast with that, Hallinan and Sorensen (1983) suggest that low ability students can benefit from this segregation because the teachers can provide them with appropriate curriculum and pace of instruction. 
In addition, grouping has been affected by diverse theories and therefore has been practiced differently. Alpert and Bechar (2008), for instance, believe despite the ideological criticism and widespread resistance against ability grouping, it is difficult to eliminate it. The same view has also been supported by the researchers who documented difficulties in defying ability grouping and its subsequent influences on inequality (e.g. Oakes, 2005; Oaks, Rogers, \& Lipton, 2006).

Further, Yonezawa, Wells, and Serna (2002) maintain No-grouping manifests itself differently in various contexts. In some schools - as they assert - No-grouping means eliminating remedial tracks, while at the same time providing tutoring and enhanced instruction for the students who struggle with higher-level courses. In others schools, however, No-grouping is a flexible regrouping of students' abilities in some courses but not in others. The idea is that the latter helps avoiding stigmatization and stagnation.

On the contrary, Rubin (2003) asserts that research on No-grouping has yielded no clear indication regarding its effect at classroom-level. Whereas quantitative studies present contradictory findings regarding the impact of No-grouping on student achievements, qualitative research reported so far indicates it is quite complicated to implement No-grouping in schools and communities (e.g. Oakes, 1997; Yonezawa, Wells, \& Serna, 2002).

Nevertheless, Betts and Shkolnik (2000) report diverse effect of ability grouping on high as well as low-achievers. Similarly, Tach and Farkas (2006) suggest in order for ability grouping to be successful, test scores should be considered as the strongest determinant, however, this needs to be followed in magnitude by the teacher's judgment of the student's learning-related classroom behavior. They also state that such variables may explain most of the race, gender, and social class differences when students are placed into various ability groups.

The issues surrounding ability grouping can also be explored by implementing an input-process-outcome model. As for the first component, input (i.e., instruction), individual factors should count the most; however, it is exactly here that the system is most likely to malfunction because as an ongoing process, grouping exposes students to different levels of academic content, academic discourse, and hence teaching quality. The second component, process, is of most concern to the teachers and curriculum developers. And finally, input (instruction) results in different learning outcomes (the third component) in high- and low-group classrooms. Outcome is the most visible component of the above model (Callahan, 2005).

Moreover, research shows that ability grouping accounts for the bulk of variation in both students' growth and achievement and that such a variation is primarily the result of greater content-area and coverage which happen due to ability grouping (Carbonaro, 2005). Slavin's (1987) grouping plans can best be explained in terms of what Carbonaro (ibid) suggest. Salvin maintains some grouping plans may be quite successful in various educational contexts. He categorises these plans as (i) ability-group class assignment (referred to by Americans as 'tracking' and by Britons as 'streaming'), (ii) ability grouping for selected subjects, (iii) Joplin plan, (iv) non-graded plans, (v) special classes for high achievers, (vi) special classes for low achievers, and (vii) within class ability grouping.

Regardless of which grouping plan the school authorities select, there are generally three ability groups; high, middle and low. However, there have been cases where educators decided to have remedial groups instead of low ability groups (Hallinan \& Sorensen, 1983; Slavin, 1987).

As discussed above by Slavin (1987), the terms used in the studies on ability grouping are different in the UK and the US. The British terms of 'setting', 'streaming', and 'mixed ability teaching' are, for instance, corresponded to 'regrouping', 'tracking', and 'heterogeneous grouping' in the US, respectively. Consequently, studies on ability grouping conducted in the UK, unlike those conducted in America, have focused on the underlying processes involved in group work (et al. Ireson, Hallam, Hack, Clark, \& Plewis, 2002); Linchevski \& Kutscher, 1998). In such studies, group interactions as well as social and ability groupings which appear to be effective on learning processes have been investigated (e.g., Hallam \& Toutounji, 1996). Studies of this type have also concentrated on the inequities of the 'setting' or 'streaming' system for those students who are allocated to low groups or streams because of the factors such as race, class or gender variation. Nevertheless, the reported studies seem to have paid little attention to the effects of 'setting' or 'streaming' on the students' grasp of the course content (Boaler, 1997).

In the US, on the other hand, studies have mainly focused on the product of grouping, or the final outcome of cognitive and affective variables within the learning context (e.g. Abadzi, 1984). Such studies have mainly focused on the average scores of the students in homogeneous and heterogeneous groups and compared them with each other. This approach has obviously ignored the processes such individuals may undergo to reach the final outcome.

It goes without mentioning that even the literature of studies on ability grouping has witnessed some contradictory findings. Such contradictions can be summarised in terms of the main hypotheses related to grouping. The traditional hypothesis states that ability grouping is conducive to students' achievement regardless of their being 
classified in high, low or middle group (Kerckhoff, 1986). This is in line with a study conducted by Newfield and McElyea (1983) in which they examined the data collected from 58000 high school seniors and sophomores for the conflicting views towards the effects of ability grouping. Their study concluded that grouping led to improved achievement and attitude towards the subject matter only in students who were grouped in regular and remedial classes.

Similarly, Slavin (1987), while commenting on Atkinson and O'Connor (1963), suggested:

Ability grouping is supposed to increase student achievement primarily by reducing the heterogeneity of the class or instructional group, making it more possible for the teacher to increase the pace and level of instruction for high achievers and provide more individual attention, repetition, and review for low achievers. It is supposed to provide a spur to high achievers by making them work harder ... and to place success within the group of low achievers, who are protected from having to compete with more able age mates. (p. 296).

In contrast with the above, Kerckhoff (1986) asserted while teachers in Britain preferred ability grouping despite its lack of empirical support, they objected to 'streaming' on philosophical grounds. Boaler (1997), related this swinging between 'setting' and 'streaming' in the UK in late twentieth century to developments in research, educational theory, and the political situation of the time.

The controversy in research into ability grouping is also observed in the studies which implemented support for the divergence hypothesis (e.g. Kerckhoff, 1986). Such a hypothesis maintains that students in high-ability groups are more successful in their academic performance, compared with those in the low-ability groups (Hallinan \& Sorensen, 1983; Kerckhoff, 1986).

To sum up, many theories have explained the effectiveness of ability grouping in promoting academic achievement. Bandura's (1997) social learning theory appears to explain the increased performance of high-ability students. Similarly, Glass's (2002) discussion on Kulik and Kulik's (1984) and Slavin's (1987 and 1990) studies on ability grouping have provided indisputable evidence concerning the benefits of grouping for high-ability students. On the same line and based on the social learning theory, Glass (2002) explained that high-ability students tend to model the behavior of other high achievers, and hence are motivated to engage in more challenging tasks. On the contrary, the low-ability students show increased tendencies to model those who are popular. This peer modeling theory seems to provide a comprehensive explanation for the differential achievement in the ability grouping context.

Concerning the above controversy in relation to ability grouping, on the one hand, and the lack of reported research on this in Iran, on the other, we decided to run the present study. The aim here is to place Iranian EFL learners into different groups according to their English ability. The number of teaching hours will be determined so that the needs of each ability group are met. This will presumably provide an appropriate educational setting for students in various groups and will therefore help them to achieve more academic success in their learning of English. More specifically, since English is considered vital to Iranian non-English major undergraduates, the focus of this study will be this group of learners only. We think such learners have been ignored by Iranian field practitioners in the last couple of decades. This research is therefore an attempt to find out if ability grouping, as one possible way for promoting learning, will significantly help non-English undergraduates to become more successful in learning English.

\section{Research Questions}

The present study addresses the following questions:

1: Does grouping learners to less-able, intermediate and advanced boost significantly the students' academic success in general English courses?

2: Do various amounts of exposure to English (2, 3, and 4 hours weekly) eliminate significant group differences among the advanced, intermediate, and less-able learners at the end of the course?

3: Does ability grouping give rise to any significant gender variation in learning English in the non-majors of English at the University of Isfahan?

\section{Method}

\subsection{Participants}

We invited 320 non-English major undergraduates of the University of Isfahan, both male and female, to participate in this study (see Table 3). The participants formed 14 classes, six of which had been grouped using a placement test (see Tolouie \& Barati, forthcoming), and the other eight had been grouped on a random basis (no placement test was involved). The participants who did take the placement test were divided into two 2-hour classes, two 3-hour classes and two 4-hour classes. These classes were different in the hours of their weekly sessions. The advanced students 
(those who got $60 \%$ to $80 \%$ of the total test score) were grouped into 2-hour classes, the intermediate students (those who got $40 \%$ to $60 \%$ of the total test score) into 3-hour classes, and the less-able students (those who got below $40 \%$ of the total test score) into 4-hour classes. This would let the researchers make appropriate instructional plans for various ability groups.

\subsection{Instruments}

The data for this study were collected through two types of tests: (i) a placement test and (ii) an end-of-the-course (achievement) examination. Each is briefly explained below.

First, a placement test was employed as a criterion for grouping the participants. The test consisted of structure, vocabulary and reading comprehension sections with 20, 30 and 50 multiple-choice items, respectively. Each correct answer was given one mark. Therefore the total test score was 100.

Second, a multiple-choice achievement test was given as the final exam to all the groups of the participants at the end of the course. This test consisted of three sections: structure, vocabulary and reading comprehension, each comprising 5, 15 and 30 items, respectively. One mark was assigned to each item in this final exam. Thus, the total test score here was 50. The test was piloted prior to the main test session with a group of 35 students of similar characteristics with those of this study's target groups. Also a group of six expert judges, all of 5 or more years of experience in teaching general English to non-major undergraduates, reviewed the test for validity purposes. The piloting phase of the study revealed that some of the instructions needed to become easier to understand, as a few test takers asked for them to be clarified. Piloting also helped the researchers in terms of establishing the time needed for the completion of the test. Finally, the performance of the test takers in the piloting phase of the study helped to estimate the reliability of this test as .84 .

\subsection{Procedures}

The collection of data happened in two phases. First, the placement test (Barati \& Tolouee, forthcoming) was administered to all the participants of the study. This was to help the researchers decide about the individuals' proficiency levels: advanced, intermediate, and less-able. These were then assigned to 2, 3, and 4-hour classes every week, respectively. The course lasted for 16 weeks (one term).

As discussed above, there were generally 14 groups of participants in the present study. Six groups were divided into various abilities based on their performance on the placement test, while eight others were divided randomly (just according to their university courses) into different classes. The random groups went through the traditional programme for their English classes: 3-hour classes weekly.

All the groups, irrespective of their abilities, were given the same text book. Also the same instructors were invited to teach the participants in different groups (i.e., ability and random groups). Moreover, to avoid discrepancies in the methodology of teaching, a two-page guideline on collaborative teaching was given to the instructors and one meeting was held for their final coordination in the method of teaching prior to the course. All this was to minimize the effect of text books and/or teaching methodologies on the performance of the participants. Further, the same number of quizzes was administered to all the participating groups throughout the term, and all the individuals sat both the course's mid-term and final exams (these two exams were officially needed for passing the course). Thus, we did our best to keep everything (teacher, text-book, teaching methodology, number of quizzes, etc) constant for all groups; the only inconsistent aspect of the study was the 'ability grouping' and its subsequent exposure limits.

Further, the amount of the groups' exposure to English helped the instructors pace their teaching according to the groups' ability. One other inconsistency in the accomplishment of this study was the time of administering the mid-term exam to the ability groups. Since the pace of teaching was noticeably different in 2 and 3-hour classes as opposed to 4-hour ones, we had to give the mid-term exam to the less-able (4-hour) classes two weeks after administering it to the other groups. We therefore needed to make a parallel test for the less-able groups although the mid-term exam was not a decisive measure for this study.

As the second phase of data collection, the same achievement test (the final exam) was administered to all the participating groups after 16 weeks of instruction. The performance of the ability groups were then compared with each other and also with that of the random groups. In so doing, a couple of statistical techniques were employed.

In the data analysis phase of the study, several statistical techniques were employed and in all the cases the participants' scores on the final exam only were put into analysis. First, in order to find out if the grouping procedure and the various amount of exposure to English caused any significant difference in the performance of the participants on the final exam of the course, an independent-samples t-test was run on the performance of ability groups, on the one hand, and random groups, on the other. 
Further, a one-way analysis of variance (ANOVA) was deployed to determine whether there is any significant difference in the performance of the ability groups on the course's final exam after being exposed to English in 2, 3, and 4-hour classes.

Finally, a two-way ANOVA was run on the scores of the three ability groups to find out if gender variation has any interaction with ability grouping in the learning of non-English undergraduates at the University of Isfahan. The next section reports the results of the data analysis phase of the study.

\section{Results}

As discussed above, separate statistical analyses were employed to address the three research questions of the present study. First, to answer the question (Does grouping students to less-able, intermediate and advanced boost significantly the students' academic success in general English courses?), an independent samples $t$-test was run on the scores of the ability and random group participants on the course's final exam. This was to determine whether the learners in the ability groups could significantly outperform those in the random groups at the end of the term. Table 1 below presents the results of this phase of study.

Table 1. Independent samples t-test on the performance of ability vs. random groups

\begin{tabular}{|c|c|c|c|c|c|c|c|c|}
\hline & & \multicolumn{2}{|c|}{$\begin{array}{l}\text { Levene's Test } \\
\text { for Equality of } \\
\text { Variances } \\
\end{array}$} & \multicolumn{5}{|c|}{ t-test for Equality of Means } \\
\hline & & $\mathrm{F}$ & Sig. & $\mathrm{T}$ & Df & $\begin{array}{l}\text { Sig. } \\
\text { (2-tailed) }\end{array}$ & $\begin{array}{l}\text { Mean } \\
\text { Difference }\end{array}$ & $\begin{array}{l}\text { Std. Error } \\
\text { Difference }\end{array}$ \\
\hline \multirow[t]{2}{*}{ score } & $\begin{array}{l}\text { Equal variances } \\
\text { assumed }\end{array}$ & 40.906 & .000 & 10.553 & 318 & .000 & 2.773 & .263 \\
\hline & $\begin{array}{l}\text { Equal variances } \\
\text { not assumed }\end{array}$ & & & 11.996 & 316.215 & .000 & 2.773 & .231 \\
\hline
\end{tabular}

As Table 1 shows, a significant difference was detected between the mean scores of the two total groups of this study $(p<.000)$. In other words, provided that the non-English major undergraduates are grouped at the beginning of the course based on their proficiency level and hence are exposed to English in various programmes, they will significantly outperform their counterparts in the random groups (those who have not undergone such grouping procedures).

As for the second research question (Do various amounts of exposure to English (2, 3, and 4 hours weekly) eliminate significant group differences among the advanced, intermediate, and less-able learners at the end of the course?), a one-way ANOVA was employed to analyse the data. This was to examine the performance of the ability groups only on the final exam of the course. Table 2 illustrates the results of this stage of data analysis.

Table 2. One-way ANOVA on the performance of ability groups only on the final exam

\begin{tabular}{llllll}
\hline & Sums of Squares & df. & Mean Square & F & Sig. \\
\hline Between Groups & 16.224 & 2 & 8.112 & 4.147 & .081 \\
Within Groups & 230.836 & 118 & 1.956 & & \\
Total & 247.060 & 120 & & & \\
\hline
\end{tabular}

It is indicated by the above Table that the amount of being exposed to English for various ability groups helped them remove the big variance observed among them at the beginning of the course. In other words, the probability level observed here in addressing the second question $(p>.081)$ is bigger than .05 and hence it shows there was no significant difference in the final mean scores of the ability groups on the course's final exam. Thus, it can be concluded that ability grouping and different levels of exposure to English could eliminate significant group differences among the less-able, intermediate, and advanced groups of the study at the end of the course.

Finally, to address the third research question (Does ability grouping give rise to any significant gender variation in learning English in the English non-majors at the University of Isfahan?), a two-way Analysis of Variance (ANOVA) was applied onto the data. This was specifically intended to determine whether the interaction between the two variables of sex and ability grouping would cause any significant difference in the performance of male and female 
non-English major undergraduates. Tables 3 and 4 below illustrate the results of this phase of data analysis.

Table 3. Descriptive statistics on the performance of male and female participants

\begin{tabular}{llll}
\hline & & Value Label & N \\
\hline \multirow{2}{*}{ ability grouping } & 1 & With & 121 \\
& 2 & Without & 199 \\
& 1 & Male & 78 \\
& 2 & Female & 242 \\
\hline
\end{tabular}

Table 4. Two-way ANOVA on ability-group male and female's performance on the course final exam

\begin{tabular}{|c|c|c|c|c|c|}
\hline Source & $\begin{array}{l}\text { Type III Sum of } \\
\text { Squares }\end{array}$ & Df & Mean Square & $\mathrm{F}$ & Sig. \\
\hline Corrected Model & $612.928^{\mathrm{a}}$ & 3 & 204.309 & 39.901 & .000 \\
\hline Intercept & 58194.181 & 1 & 58194.181 & 11365.260 & .000 \\
\hline Treat & 564.493 & 1 & 564.493 & 110.245 & .000 \\
\hline Sex & 2.092 & 1 & 2.092 & .409 & .523 \\
\hline Treat $*$ sex & 33.948 & 1 & 33.948 & 6.630 & .010 \\
\hline Error & 1618.033 & 316 & 5.120 & & \\
\hline Total & 79944.005 & 320 & & & \\
\hline Corrected Total & 2230.961 & 319 & & & \\
\hline
\end{tabular}

As Table 4 indicates, although sex by itself did not affect the participants' academic success significantly $(p>.523)$, when the interaction of sex and treatment (i.e., ability grouping) was taken into consideration, the performance of the participants was significantly different $(p<.01)$. Thus, the answer to the third research question of this study indicated that a significant difference could be detected in the performance of non-English major undergraduates when the two variables of sex and ability grouping interacted with each other. It can therefore be concluded that ability grouping gives rise to a significant gender variation in the learning of non-majors of English at the University level.

\section{Discussion}

This research indicated that non-English major undergraduates who were grouped based on their English abilities could at the end of the term significantly outperform their random counterparts in learning general English. This seems to support Kerckhoff (1986) who believed high ability students can move faster when they are separated from their less competent peers. The same finding is also in line with Hallinan and Sorensen (1983) who maintained low ability students could benefit from being separated from their high ability friends because the teachers could provide them with appropriate curriculum and pace of instruction.

Further, the fact that ability groups significantly outperformed their random counterparts may be in line with the, so called, 'traditional hypothesis' in the field. The traditional hypothesis, as discussed above, maintains that ability grouping is helpful to all learners irrespective of their ability (Kerckhoff, 1986). However, the same finding seems to contradict that of Newfield and McElyea (1983) who suggest ability grouping functioned to the advantage of remedial classes (i.e., less-able students) only. In this research, however, it was found that the three ability groups did not function significantly differently on the course's final (achievement) exam. Nevertheless, when the function of the total ability groups on the same test was compared with that of the random groups of the study, a significant improvement could be detected on the part of the ability groups.

Another finding of the present research could be summarised as the positive effect of various level of exposure to English (2, 3, and 4 hours weekly) for ability groups on removing the big variance among them. As discussed above, the ability groups who were classified based on their performance on the placement test were grouped as advanced ( $60 \%$ to $80 \%$ of the total test score), intermediate ( $40 \%$ to $60 \%$ of the total test score) and less-able ( $-40 \%$ of the total test score). The analysis of the final test scores of the same groups revealed that there was no significant difference in their performance at the end of the course. This, as discussed above, may suggest that the various 
amounts of exposure to English have helped the teachers and also the course designers to put more time and efforts into the programme for less-able individuals and hence help them remove their problems in English to a meaningful degree. This seems to support Slavin's (1987) idea in relation to the effect of ability grouping on promoting the students' achievement of the course. Slavin maintains ability grouping supports students' achievement mainly by reducing the heterogeneity of the class. This, in turn, makes it more possible for the teacher to increase the pace and level of instruction for high achievers and provide more individual attention, repetition, and review for low achievers. It also provides more opportunity to high achievers to work harder and, at the same time, brings more success to the group of low achievers.

Finally, the present study revealed that although male and female participants in the ability groups did not have any significant difference in their performance on the course's final exam, when their performance was analysed in terms of the interaction between ability grouping and gender, significant improvement was revealed. This again signifies the placement process in relation to non-English majors at university level. The study directs the attention of EFL policy makers and curriculum developers worldwide, in general, and in Iran, in particular, to put more emphasis into ability grouping and exposure limits for all EFL learners, irrespective of their gender.

\section{Pedagogical Implications}

The finings of this study seem to be beneficial to university officials in countries where English is not the language of the society. In Iran, for instance, the three-hour programme for teaching English to non-majors undergraduates every week seems quite insufficient in helping the learners cope with their understanding of specialized English texts. The fact that students are accessed by English teachers for quite a limited amount of time makes it vital to plan the most beneficial programme for them. This should be so that the best use could be made of the available time. The study therefore suggests that both ability grouping and planning specific programmes for various groups are extremely necessary for the learners of English in any country where English is not the language of the society.

In line with the above, the findings of this study suggest that university officials need to pay more attention to the methodology of teaching English to non-major undergraduates. Innovative methods of teaching - collaborative learning in the case of this study, appropriate text-books which go with the employed methodology, in-service education for the English teachers, and close cooperation between teachers and university officials might seem vital in this respect.

\section{Conclusion}

Hudson and Blain (1989) assert that the first year of university education is one of the most reliable predicators of students' persistence and successful graduation. In Iran, the course of general English is offered to non-majors in the first year of their university education. The idea therefore is that if the findings of the present study are put to work by the English practitioners at university level in this country or any country with the similar undergraduate curriculum, the first year of education at the university could be changed to a very pleasant and productive one, at least, with reference to learning English. If ability grouping is conducted with the appropriate teaching plan for various groups, and provided that the teachers pace their teaching so that it goes with the students' learning process, the freshmen's academic success will not be far and learning English would change to an enjoyable activity.

This study is nevertheless a step forward in teaching English in the context of adult EFL learners. It will surely inform further research in the field and - let us hope - will eventually bring changes in the way English is taught to non-majors at university level both in Iran and elsewhere.

\section{Limitations of the Study}

The present study has certain limitations that need to be taken into account when considering the study and its contributions. Some of these limitations can be seen as fruitful avenues for future research under the same theme. First, the study only includes Iranian non-English major undergraduates of the University of Isfahan, so that the results may not apply directly to all countries in the world. Second, due to the use of a non-standardized placement test, the findings may not be able to predict the behavior of a wide classification of people.

Overall, while the study has its contributions to the field of EFL teaching, it is clear that more detailed national and international level studies should be undertaken to produce findings generalizable to larger classifications of people.

\section{References}

Abadzi, H. (1984). Ability grouping: Effects on academic achievement and self-esteem in a southwestern school district. Journal of Educational Research, 77(5), 287-292.

Alpert, B., \& Bechar, S. (2007). Collaborative evaluation research: A case study of teachers' and academic researchers' teamwork in a secondary school. Studies in Educational Evaluation, 33(3-4), 229-257. 
http://dx.doi.org/10.1016/j.stueduc.2007.07.003

Atikinson J. W., \& O'Connor, P. Effects of Ability Grouping in Schools Related to Individual Differences in Achivement-Related Motivation: Final Report. U.S. Office of Education Cooperative Research Project 1238, 1963.

Argy, L. M., Rees, D. I., \& Brewer, D. J. (1996). Detracking America's schools: Equity at zero cost? Journal of Policy Analysis and Management, 15(4), 623-645.

Bandura, A. (1997). Self-efficacy: the exercise of control. New York: W. H. Freeman.

Barati, H., \& Tolouee, B. (Forthcoming). Planning, developing, and validating a placement test for Iranian non-English undergraduates. Journal of Teaching Language Skills.

Bednarek, M. (2008). Emotion Talk across Corpora. London: Palgrave. http://dx.doi.org/10.1057/9780230285712

Betts, J. R., \& Shkolnik, J. L. (2000). The effects of ability grouping on student math achievement and resource allocation in secondary schools. Economics of Education Review, 19(1), 1-15. http://dx.doi.org/10.1016/S0272-7757(98)00044-2

Boaler, J. (1997). Setting, social class, and ability. British Educational Research Journal, 23(1).

Callahan, R. M. (2005). Tracking and high school English learners: Limmiting opportunity to learn. American Educational Research Journal, 2(42), 305-328.

Carbonaro, W. (2005). Tracking, students_effort, and academic achievement. Sociology of Education, 78, $27-49$.

Glass, G. V. (2002). Grouping students for instruction. In A.Molnar (Ed.), School reform proposals: The research evidence, research in educational productivity series. Greenwich, CT: Information Age Publishing.

Hallam, S., \& Touounji, I. (1996). What do we know about the grouping of pupils by ability: A research review. Institute of Education, University of London.

Hallinan, \& Sorensen. (1983). Tracking: from theory to practice. Sociology of Education, 67(2), 79-84.

Hudson, J. Blaine. (1989). An Analysis of ACT Scores, Placement Tests, and Academic Performance in Reading, English, and Mathematics (ERIC Document Reproduction Service No. ED 334 916).

Ireson, J., Hallam, S., Hack, S., Clark, H., \& Plewis, I. (2002). Ability grouping in English secondary school: Effects on attainment in English, Mathematics, and Science. Educational Research and Evaluation: An International Journal on Theory and Practice, 8(3), 299-318.

Kerchkoff, A. C. (1986). Effects of ability grouping in British secondary schools. American Sociological Review, 51(6), 842-858. http://dx.doi.org/10.2307/2095371

Kulik, J. A., \& Kulik, C. C. (1984A). Effects of accelerated instruction onstudents. Review of Educational Research, $54,409-425$.

Linchevski, L., \& Kutscher, B. (1998). Tell me with whom you're learning, and I'll tell you how much you've learned: Mixed-ability versus same ability grouping in mathematics. Journal for Research in Mathematics Education, 29(5), 533-554.

Newfield, J., \& McElyea, V. B. (1983). Achievement and attitudinal differences in regular, remedial and advanced classes. Journal of Experimental Education, 52(1), 47-56.

Oakes, J. (2005). Keeping track: How schools structure inequality (2nd ed.). New Haven, CT: Yale University Press.

Oakes, J., Wells, A. S., Jones, M., \& Dantnow, A. (1997). Detracking: The social construction of ability, cultural politics, and resistance to reform. Teacher's College Record, 98, 483-510.

Oaks, J., Rogers, J., \& Lipton, M. (2006). Learning power: Organizing for education and justice. New York, NY: Teachers College Press.

Rubin, B. C. (2003). Unpacking detracking: When progressive pedagogy meets students' social worlds. American Educational Research Journal, 40(2), 539-573. http://dx.doi.org/10.3102/00028312040002539

Seidlhofer, B. (2004). Annual Review of Applied Linguistics, 24, 209-39. Cambridge: Cambridge University Press.

Slavin, R. E. (1987). Ability grouping and student achievement in elementary schools: A best evidence synthesis. Review of Educational Research, 57(3), 293-336.

Slavin, R. E. (1990). Achievement effects of ability grouping in secondary schools: A best evidence synthesis. Review of Educational Research, 60(3), 471-499.

Tach, L., \& Farkas.G. (2006). Learning-related behaviors, cognitive skills, and ability grouping when schooling 
begins. Social Science Research, 35(4), December, 1048-1079.

Yonezawa, S., Wells, A., \& Serna, I. (2002). Choosing tracks: Freedom of choice in detracking schools. American Educational Research Journal, 39(1), 37-67. http://dx.doi.org/10.3102/00028312039001037 